\title{
Alternatively Spliced Nephrin in Experimental Glomerular Disease of the Rat
}

\author{
PAULIINA LUIMULA, PETRI AALTONEN, HEIKKI AHOLA, TUULA PALMEN, AND \\ HARRY HOLTHÖFER
}

Haartman Institute, Department of Bacteriology and Immunology, 00014-University of Helsinki and Helsinki University Central Hospital, 00029 HUCH, Finland

\section{ABSTRACT}

\begin{abstract}
Nephrin is a novel transmembrane protein of kidney glomerular podocytes, which appears crucially important for the maintenance of the glomerular filtration barrier. According to its predicted structure, nephrin has additional roles in cell-cell adhesion and/or signal transduction. We have previously cloned the rat homologue of nephrin and described its alternatively spliced transcripts alpha and beta. In this study we examined the alterations in expression and regulation of particularly the major alternatively spliced nephrin-alpha giving rise to a variant lacking the membrane spanning domain in the puromycin nephrosis of the rat. A down-regulation of up to $78 \%$ was observed of the full length mRNA after $10 \mathrm{~d}$ of PAN treatment. The expression changes of nephrin-alpha followed closely the expression of the full length mRNA. Interestingly,
\end{abstract}

we also found nephrin protein in urine at the peak proteinuria samples of this model. These results suggest that soluble nephrin variants may be important markers for proteinuric diseases. (Pediatr Res 48: 759-762, 2000)
Abbreviations:
PAN, puromycin aminonucleoside nephrosis
CNF, congenital nephrotic syndrome of the Finnish type
RT-PCR, reverse transcriptase PCR
M-MLV RT, Moloney murine leukemia virus reverse transcriptase

Mutations in the newly identified NPHS1 gene cause the congenital nephrotic syndrome of the Finnish type (CNF). NPHS1 encodes a transmembrane protein, nephrin, with eight immunoglobulin-like and one fibronectin III-like module as well as a transmembrane and intracellular domain (1). Nephrin appears to be primarily located in the slit diaphragm area of podocytes (2-5) while distinct protein expression can also be found at the lateral podocyte membranes $(2,3,6)$. Nephrin is thought to be essentially involved in the assembly of filtration barrier of glomerulus. Thus far a variety of mutations, in addition to those preferentially found in Finland, have been described from all over the world $(7,8)$ and are invariantly associated with proteinuria. Interestingly, renephrosis after renal transplantation associates with high level of circulating antinephrin antibodies in CNF patients suggesting of a direct pathogenic role of the circulating antibodies (Wang et al., unpublished). In support to this, Topham et al. (9) have shown that in vivo injection of antibodies apparently identifying the extracellular domain of nephrin in the rat similarly induces heavy transient proteinuria.

Received March 30, 2000; accepted August 8, 2000.

Correspondence and reprint requests: Harry Holthöfer, M.D., Ph.D., The Haartman Institute, Division of Bacteriology and Immunology, PB 21 (Haartmaninkatu 3), FIN00014 University of Helsinki, Finland.

This study was supported by the Finnish Society of Nephrology, Helsinki University Hospital, Päivikki and Sakari Sohlberg Foundation and the Sigrid Juselius Foundation and the Finnish Academy.
Experimental nephrosis of the rat induced with puromycin aminonucleoside (PAN) is widely used to study the mechanisms of proteinuria (10-12). The phenotype of PAN nephrosis resembles closely the morphologic and functional changes of the human "minimal change" disease in which the transient "fusion" and effacement of the podocyte foot processes leads to the loss of the ultrafiltration barrier $(13,14)$.

We have recently cloned the rat homologue of nephrin and described its alternatively spliced mRNA variants alpha and beta (2). The alpha variant lacks the exon coding for the transmembrane area and thus presumably produces a truncated soluble form of nephrin. Thus far nothing is known of the role the various splicing variants. In the human kidney we have described one splicing variant similarly lacking the transmembrane domain (3). Thus, the experimental rat models appear particularly suitable to study the role of soluble nephrin forms.

Here we describe the expression pattern changes of nephrinalpha mRNA in PAN nephrosis by semiquantitative reverse transcriptase PCR (RT-PCR) and on protein level by immunoblotting.

\section{MATERIALS AND METHODS}

Animal experiments. Young male rats of Sprague-Dawley strain $(n=18)$ weighing 250-280g (Department of Bacteriology and Immunology, University of Helsinki) were used in 
this study. The animals were fed with standard rat chow and had free access to tap water. Rats were given a single intraperitoneal injection of puromycin (puromycin aminonucleoside $15 \mathrm{mg} / 100 \mathrm{~g}$, Sigma Chemical Co. Chemicals, St. Louis, MO, U.S.A.). The control group received $0.9 \%$ saline i.p. in equal amounts at day 0 of puromycin injection. Urine was collected using metabolic cages at day $0,3,6$, and 9. All PAN-treated animals developed albuminuria, which was measured by nephelometry (Behring Nephelometer 100 analyzer, Behringwerke, Marburg, Germany). Animals treated with PAN were killed at day $3(n=6)$ and $10(n=6)$, while untreated control animals $(n=6)$ were all killed day 10. Samples of cortical kidney tissue were taken after sacrifice to semiquantitation of RNA. The rest of cortical tissues were sectioned and snap frozen in liquid nitrogen and stored at [minus] $70^{\circ} \mathrm{C}$ until used. Collected urine samples were stored for immunoblot studies as described earlier (15).

$\boldsymbol{R N A}$ isolation. Cortical kidney RNA was isolated either immediately after sacrifice or from the frozen pieces of tissue $(50-150 \mathrm{mg})$ by the single-step acid guanidinium-thiocyanatephenol-chloroform procedure using Trizol ${ }^{\circledR}$ reagent (Life Technologies, GIBCO BRL, Paisley, Scotland) according to manufacturers instructions. For the removal of genomic DNA, the RNAs obtained were incubated with RNase free DNase I (Promega, Madison, WI, U.S.A.) for $30 \mathrm{~min}$ in $37^{\circ} \mathrm{C}$ together with human placental RNase inhibitor (Promega).

Semiquantitative RT-PCR. For the detection of different nephrin splicing forms semiquantitative reverse transcriptase PCR (RT-PCR) instead of less sensitive Northern blotting showed to be useful (16). For this, cDNA was first synthesized with the Moloney Murine Leukemia Virus reverse transcriptase (M-MLV RT) enzyme (Promega) in the presence of oligo $\mathrm{dT}_{15}$-primer (Boehringer Mannheim) and an RNase inhibitor. The amounts of cDNA were equalized according to the $\beta$-actin levels. Sequence-specific oligonucleotide primers were designed according to rat nephrin sequence. The primers used only anneal to the alpha splicing variant (upper 5'agcctcttgaccatcgctaa; RN-S3 and lower 5'gtcctcgecttcagcacctg; RN-alpha) corresponding to 480 nucleotides. In previous studies primers amplifying the full length nephrin mRNA (upper RN-S3 and lower 5'ggccataggctctctccact; RN-AS2) were used (see Fig. 1.).

PCR amplifications were performed (total volume $25 \mu \mathrm{L}$ ) in the presence of $0,5 \mu \mathrm{M}$ each of the specific oligonucleotide primers, 0,2mM dNTP (Finnzymes, Espoo, Finland), 10X PCR

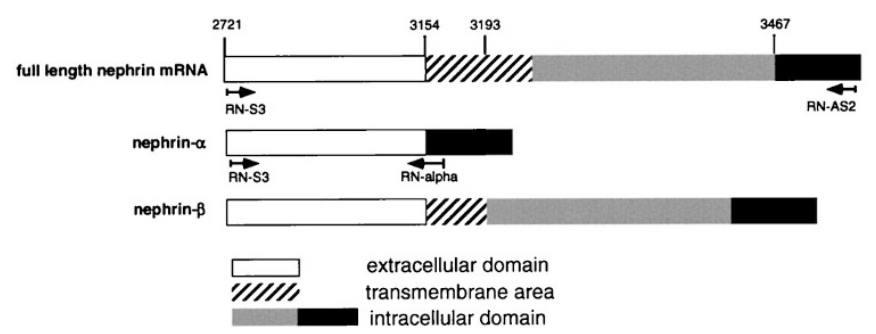

Figure 1. Schematic illustration of PCR primers used to amplify full length rat nephrin mRNA and splicing variant nephrin-alpha. The numbers indicate nucleotides of rat nephrin (gene bank \#AF125521). For detailed primer sequences see materials and methods.
Buffer with $15 \mathrm{mM} \mathrm{MgCl}{ }_{2}$ (Perkin-Elmer, Cetus, Norwalk, CT, U.S.A.) and 1U AmpliTaq polymerase (Perkin-Elmer) for $\beta$-actin primers for 28 cycles or 32 cycles for nephrin primers (in first cycle denaturation was $3 \mathrm{~min}$ in $94^{\circ} \mathrm{C}$ and thereafter $45 \mathrm{~s}$, annealing at $56^{\circ} \mathrm{C}$ for $1 \mathrm{~min}$ and extension at $72^{\circ} \mathrm{C} 45 \mathrm{~s}$ ).

PCR products were electrophoresed in $6 \%$ polyacrylamide gel and quantified with the National Institutes of Health Image ${ }^{\circledR}$ program as described previously (16)

Real-time quantitative PCR. To verify the expression level differences of nephrin transcripts as seen in the semiquantitation we used a novel real-time fluorescence based PCR detection method (TaqMan technology®; PE Applied Biosystems, Foster City, CA, U.S.A.) $(17,18)$. This PCR method is based on the $5^{\prime}$ to $3^{\prime}$ exonuclease activity of Taq polymerase, which cleaves an internal probe during PCR amplification reaction. The probe (24bp), designed between nephrin specific primers (upper 2709 and lower 2783), is labeled with a reporter dye at its $5^{\prime}$ end and a quencher dye at its $3^{\prime}$ end. The fluorescent PCR products $(74 \mathrm{bp})$ were detected with the appropriate instrumentation (PE Biosystems model 7700).

Immunoblotting. Urine samples were electrophoresed in $8 \%$ SDS (SDS) polyacrylamide gels with reducing conditions and electrotransferred to nitrocellulose membrane (Scleicher \& Schuell, Dassel, Germany). Thereafter the membrane was blocked by incubating with $3 \%$ BSA to prevent unspecific binding. Primary polyclonal rabbit anti-nephrin antibody directed at the extracellular part of nephrin (2), used at 1:300 (diluted in PBS/0.1\% Tween-20) was applied for $60 \mathrm{~min}$ at room temperature. After several rinses with PBS $/ 0.1 \%$ Tween20, a secondary antibody (horseradish peroxidase-conjugated swine anti-rabbit immunoglobulins (Dako, Glostrup, Denmark) was used at 1:2000.

Statistics. Results shown are mean values \pm SD. The significance of results were evaluated by Mann-Whitney U test; $p<$ 0.05 were considered significant.

\section{RESULTS}

Urinary albumin. Animals treated with puromycin developed albuminuria starting at day $3(3.6 \pm 5.3 \mathrm{mg} / 24 \mathrm{~h}$ versus controls $0.5 \pm 0.2 ; p<0.05)$, which reached its maximum at day $6(373.3 \pm 166.5 \mathrm{mg} / 24 \mathrm{~h}$ versus controls $0.35 \pm 0.15$ $\mathrm{mg} / 24 \mathrm{~h} ; p=0.05$ and at day 9 was $344.5 \pm 104.1 \mathrm{mg} / \mathrm{d}(p<$ $0.01)$; see Fig. 2.

Semiquantitative RT-PCR and real-time PCR. A 40\% reduction in the expression of nephrin-alpha mRNA was seen already at day 3 after PAN treatment and after $10 \mathrm{~d}$ of treatment the expression was only $30 \%$ of the expression level of controls (Fig. 3). Close similarity in the decrease of expression to full length nephrin mRNA was obvious as previously shown (2).

To verify the adequate precision of the semiquantitation method we performed additional assay of the total mRNA level using the TaqMan ${ }^{\circledR}$ real-time PCR analysis. The values correlated well with those of the semiquantitation (Table 1).

Immunoblotting. In the urine samples from PAN treated rats 6 and $10 \mathrm{~d}$ after injection the immunoblotting analysis revealed a faint but distinct band size of $166 \mathrm{kD}$ (Fig. 4.) while no 


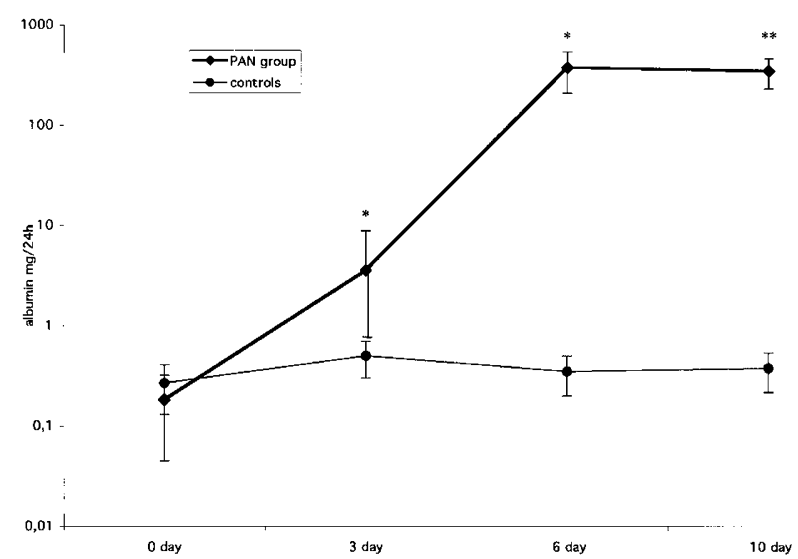

Figure 2. Urinary albumin (in $\mathrm{mg} / 24 \mathrm{~h}$ ) in PAN treated rats and controls at days $0,3,6$, and $9 .{ }^{* *} p<0.01 ;{ }^{*} p=0.05 v s$ mean of the control.

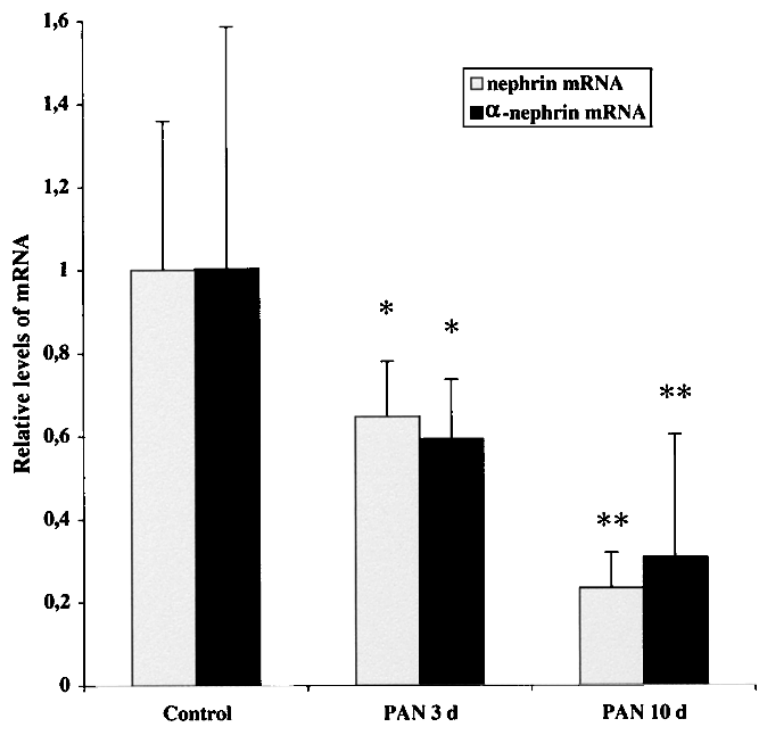

Figure 3. Semiquantitative RT-PCR study with nephrin mRNA and nephrinalpha mRNA after 3 and $10 \mathrm{~d}$ of PAN treatment. ${ }^{*} p<0.01 ;{ }^{*} p<0.05 v \mathrm{~s}$ mean of the control. The amount of samples for nephrin mRNA was 3 and for $\alpha$-nephrin 6 per group.

Table 1. Comparison of results with semiquantitative RT-PCR and real-time quantitative PCR (TaqMan $\left.{ }^{\circledR}\right)$ in detecting the expression levels of full length nephrin $m R N A$

\begin{tabular}{lcc}
\hline & Semiquantitative PCR & Real-Time PCR \\
\hline Control & 1 & 1 \\
PAN 3 day & 0.65 & 0.59 \\
PAN 10 day & 0.23 & 0.23 \\
\hline
\end{tabular}

nephrin-specific band could be observed in the day 0 and 3 urine samples of low proteinuria. The size of the band suggested it to be the splicing form alpha.

\section{DISCUSSION}

In this study we characterize the regulation of the previously reported (2) nephrin-specific mRNA splicing in the puromycin nephrosis of the rat. Here we also show that nephrin can be detected among urinary proteins when the level of proteinuria exceeds $25 \mathrm{mg} / \mathrm{mL}$ in this experimental rat model. Whether the other commonly used experimental models of glomerular dam-

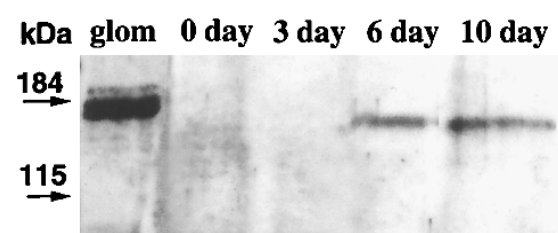

Figure 4. Immunoblotting analysis of nephrin from urines of PAN treated rats with polyclonal anti-nephrin antibodies against the extracellular domain. Size of the blotted band (around $166 \mathrm{kD}$ ) apparently presents the truncated form nephrin-alpha.

age result in a similar release of nephrin and, particularly, what is the precise role of the soluble nephrin variants for the disease phenotype remains to be established in detail.

Nephrin was recently identified as a major structural component of the poorly understood yet functionally central structure of the glomerular filtration barrier (2-5), but little is still known of its exact functions. Interestingly, Topham et al. (9) could only recently show that the epitope of the previously introduced MAb MoAb 5-1-6 is nephrin. Earlier the MoAb 5-1-6 was shown to induce transient massive proteinuria when injected in the rat in vivo (19). Our observations with i.v. injection of antibodies to different extracellular domains of nephrin agree with these results (Holthöfer et al., unpublished). Ruotsalainen et al. (5) have suggested a zipper-like organization of nephrin molecules extending from both sides of adjacent podocyte foot processes, forming a structural scaffold for the filtration barrier. Other proteins involved in the poorly known filtration slit organization include presumably at least P-cadherin (20), possibly synaptopodin (21) and (from the intracellular the tight junction aspect) ZO-1 (22). In addition to these data, Furness et al. could show regulation of nephrin mRNA in human acquired nephrotic syndrome (23).

The possibility that local regulation of nephrin functions are modulated by usage of alternatively spliced forms is intriguing. The splicing variant expression pattern in the rat and human kidney resembles closely each other $(2,3)$. In analogy to nephrin splicing, modulation of local receptor functions by releasing soluble protein is e.g. known for angiotensin II receptors, interleukin receptors and some $\mathrm{T}$ cell receptors (24-26). There is, however, only indirect evidence based on the predicted amino acid sequence of proposed nephrin functions in receptor mediated signaling (1). Here we got conclusive evidence that the alpha variant follows closely the expression pattern of the full length mRNA, is translated into protein and apparently secreted into the urine. The full functional relevance of the splicing variants in human and rat glomerular diseases, however, remain to be characterized in detail. Earlier data have shown that nephrin protein is found in the interpodocyte filtration slits (1-4) although some nephrin is always present at the podocyte plasma membranes $(2,3)$. Our further studies have shown an increase in the plasma membrane localization of nephrin in experimental renal disease as detected by immunoelectron microscopy (27). Whether this represents an increase in the protein product of the splicing variant is not known. However, the detection of the splicing variant as shown here supports the following hypothesis: under normal conditions only minor amounts of the soluble nephrin variant is translated and cannot be detected in the urine. In diseased glomeruli, instead, 
an efficient translation of the splice variant is induced, leading also to major leakage of the soluble nephrin. Since the puromycin model may also lead to direct damage of podocytes with release of all epitopes into urine, other less damaging models of glomerular injury, as well as detailed mechanisms of intracellular mRNA processing should be studied. We are currently developing antibody tools to identify readily the splicing variants thus allowing the detailed analysis of translation to proteins.

Acknowledgments. The expert assistance of Liisa Pirinen is gratefully acknowledged.

\section{REFERENCES}

1. Kestilä M, Lenkkeri U, Mannikkö M, Lamerdin J, McCready P, Putaala H, Ruotsalainen V, Morita T, Nissinen M, Herva R, Kashtan C, Peltonen L, Holmberg C, Olsen A, Tryggvason K 1998 Positionally cloned gene for a novel glomerular protein-nephrin is mutated in congenital nephrotic syndrome. Mol Cell 1:575-582

2. Ahola H, Wang SX, Luimula P, Solin ML, Holzman LB, Holthofer H 1999 Cloning and expression of the rat nephrin homolog. Am J Pathol 155:907-913

3. Holthöfer H, Ahola H, Solin M-L, Wang S, Luimula P, Miettinen A, Kerjaschki D 1999 Nephrin localizes at the podocyte filtration area and is characteristically spliced in the human kidney. Am J Pathol 155:1681-1687

4. Holzman LB, St John PL, Kovari IA, Verma R, Holthofer H, Abrahamson DR 1999 Nephrin localizes to the slit pore of the glomerular epithelial cell - Rapid Communication. Kidney Int 56:1481-1491

5. Ruotsalainen V, Ljungberg P, Wartiovaara J, Lenkkeri U, Kestilä M, Jalanko H, Holmberg C, Tryggvason K 1999 Nephrin is specifically located at the slit diaphragm of glomerular podocytes. Proc Natl Acad Sci USA 96:7962-7967

6. Okasora T, Nagase M, Kawachi H, Matsui K, Orikasa M, Morioka T, Yamazaki I, Oite T, Shimizu F 1991 Altered localization of antigen recognized by proteinuriainducing monoclonal antibody in experimental nephrosis. Virchows Arch B Cell Pathol Incl Mol Pathol 60:41-46

7. Aya K, Tanaka H, Seino Y 2000 Novel mutation in the nephrin gene of a japanese patient with congenital nephrotic syndrome of the Finnish type. Kidney Int 57:401404

8. Bolk S, Puffenberger EG, Hudson J, Morton DH, Chakravarti A 1999 Elevated frequency and allelic heterogeneity of congenital nephrotic syndrome, Finnish type, in the old order Mennonites. Am J Hum Genet 65:1785-1790

9. Topham P, Kawachi H, Haydar S, Chugh S, Addona T, Charron K, Holzman L, Shia M, Shimizu F, Salant D 1999 Nephritogenic mAb 5-1-6 is directed at the extracellular domain of nephrin. J Clin Invest 104:1559-1566

10. Mahan JD, Sisson-Ross S, Vernier RL 1986 Glomerular basement membrane anionic charge site changes early in aminonucleoside nephrosis. Am J Pathol 125:393-401
11. Messina A, Davies DJ, Dillane PC, Ryan GB 1987 Glomerular epithelial abnormalities associated with the onset of proteinuria in aminonucleoside nephrosis. Am J Pathol 126:220-229

12. Whiteside C, Prutis K, Cameron R, Thompson J 1989 Glomerular epithelial detachment, not reduced charge density, correlates with proteinuria in adriamycin and puromycin nephrosis. Lab Invest 61:650-660

13. Vernier R, Papermaster B, Good R 1959 Aminonucleoside nephrosis: I. Electronmicroscopic study of renal lesions in rats. J Exp Med 109:115-126

14. Caulfield JP, Reid JJ, Farquhar MG 1976 Alterations of the glomerular epithelium in acute aminonucleoside nephrosis. Evidence for formation of occluding junctions and epithelial cell detachment. Lab Invest 34:43-59

15. Holthöfer H, Reivinen J, Miettinen A 1994 Nephron segment and cell-type specific expression of gangliosides in the developing and adult kidney. Kidney Int 45:123-130

16. Holthöfer H, Kretzler M, Haltia A, Solin ML, Taanman JW, Schagger H, Kriz W, Kerjaschki D, Schlondorff D 1999 Altered gene expression and functions of mitochondria in human nephrotic syndrome. FASEB J 13:523-532

17. Gibson UEM, Heid CH, Williams PM 1996 A novel method for real time quantitative RT-PCR. Genome Res 6:99-1001

18. Laurendeau I, Bahuau M, Vodovar N, Larramendy C, Olivi M, Bieche I, Vidaud M, Vidaud D 1999 TaqMan PCR-based gene dosage assay for predictive testing in individuals from a cancer family with INK4 locus haploinsufficiency. Clin Chem 45:982-986

19. Kawachi H, Matsui K, Orikasa M, Morioka T, Oite T, Shimizu F 1992 Quantitative studies of monoclonal antibody 5-1-6-induced proteinuric state in rats. Clin Exp Immunol 87:215-219

20. Reiser J, Kriz W, Kretzler M, Mundel P 2000 The glomerular slit diaphragm is a modified adherens junction. J Am Soc Nephrol 11:1-8

21. Mundel P, Heid HW, Mundel TM, Kruger M, Reiser J, Kriz W 1997 Synaptopodin: an actin-associated protein in telencephalic dendrites and renal podocytes. J Cell Biol 139:193-204

22. Kurihara H, Anderson JM, Farquhar MG 1992 Diversity among tight junctions in rat kidney: glomerular slit diaphragms and endothelial junctions express only one isoform of the tight junction protein ZO-1. Proc Natl Acad Sci USA 89:7075-7079

23. Furness P, Hall L, Shaw J, Pringle J 1999 Glomerular expression of nephrin is decreased in acquired human nephrotic syndrome. Nephrol Dial Transplant 14:12341237

24. Pupilli C, Lasagni L, Romagnani P, Bellini F, Mannelli M, Misciglia N, Mavilia C, Vellei U, Villari D, Serio M 1999 Angiotensin II stimulates the synthesis and secretion of vascular permeability factor/vascular endothelial growth factor in human mesangial cells. J Am Soc Nephrol 10:245-255

25. Junghans RP, Waldmann TA 1996 Metabolism of Tac (IL2Ralpha): physiology of cell surface shedding and renal catabolism, and suppression of catabolism by antibody binding. J Exp Med 183:1587-1602

26. Takase K, Okazaki Y, Wakizaka K, Shevchenko A, Mann M, Saito T 1998 Molecular cloning of pTAC12 an alternative splicing product of the CD3gamma chain as a component of the pre-T cell antigen-receptor complex. J Biol Chem 273:3067530679

27. Luimula P, Ahola H, Wang S-X, Solin M-L, Aaltonen P, Tikkanen I, Kerjaschki D, Holthofer H 2000 Nephrin in experimental glomerular disease. Kidney Int 58:14611468 